\title{
America pushes to overhaul chemical safety law
}

When it comes to commercial chemicals, the presumption of innocence may be coming to an end. The Toxic Substances Control Act (TSCA) allows the US Environmental Protection Agency (EPA) to test chemicals that pose a health risk - but only when it has evidence of harm. Since the law was passed in 1976, the agency has restricted just five chemicals, out of tens of thousands on the market. "It's a deeply flawed bill that needs to be rewritten," says Terry Davies, an environmental policy expert who worked on the act and is now at Resources for the Future, a nonprofit research organization in Washington DC.

Congress is likely to take up a bill this spring that would shift the burden of proof on to manufacturers; a hearing in a Senate subcommittee is scheduled for 4 February. Advocates for reform are pushing for potential legislation to include scientific advances in recent decades, such as how chemicals affect people at different ages and how multiple chemicals interact in the body.

The TSCA gave the EPA the authority to regulate chemicals and chemical mixtures not covered under laws for food, drugs, cosmetics and pesticides. But the 62,000 chemicals that were already on the market in 1976 were exempted. Of 21,000 chemicals registered since 1976 , only $15 \%$ were submitted with any health-and-safety data, and the EPA has been able to require testing for only about 200 chemicals. About $95 \%$ of notices of new chemicals include confidential information, ostensibly to protect company trade secrets; this effectively prevents scientists outside the EPA from challenging the chemicals' safety.

With the TSCA essentially toothless, state officials have emerged as key watchdogs,

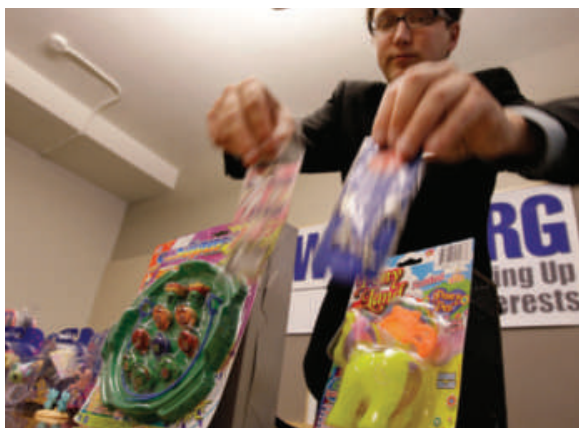

Many worry about toxic chemicals in toys.

banning chemicals in toys and elsewhere (see 'Patchy regulation') and supporting research into non-toxic alternatives.

But in December, Lisa Jackson, the head of the EPA, told Congress that the TSCA needed to be "updated and strengthened". She has also tapped into some unused regulatory tools available under current law. In late December, for instance, the EPA for the first time drew up a list of "chemicals of concern", including action plans that "outline the risks that each chemical may present". The list included phthalates endocrine-disrupting plastic additives already banned in toys in Europe and several US states - along with three other classes of chemicals. And last month, Jackson announced that the agency would no longer keep confidential the names of chemicals that companies report as posing a substantial risk to health and the environment.

Further impetus for reform has come from an unexpected place: the chemical industry. Last year, the American Chemistry Council in Washington DC and other trade organizations announced their support for

\begin{tabular}{|c|c|c|c|}
\hline \multicolumn{4}{|c|}{ PATCHY REGULATION } \\
\hline Chemical & Application & Potential health links & Regulations \\
\hline Bisphenol A & $\begin{array}{l}\text { Plastic bottles, food } \\
\text { cans }\end{array}$ & $\begin{array}{l}\text { Prostate cancer, coronary } \\
\text { heart disease }\end{array}$ & $\begin{array}{l}\text { Banned from baby bottles } \\
\text { in Connecticut (2009) and } \\
\text { Minnesota (2010) }\end{array}$ \\
\hline Phthalates & Plastic products & $\begin{array}{l}\text { Reproductive disorders, } \\
\text { obesity }\end{array}$ & $\begin{array}{l}\text { Federal ban on several phthalates in } \\
\text { toys ( } 2008)\end{array}$ \\
\hline $\begin{array}{l}\text { Perfluorooctanoic } \\
\text { acid (PFOA) }\end{array}$ & $\begin{array}{l}\text { Teflon and other } \\
\text { non-stick cookware }\end{array}$ & $\begin{array}{l}\text { Thyroid disease, fertility } \\
\text { problems }\end{array}$ & EPA "chemical of concern" (2009) \\
\hline DecaBDE & Fire retardant & $\begin{array}{l}\text { Cancer, brain development } \\
\text { problems }\end{array}$ & $\begin{array}{l}\text { State bans, voluntary phase-out } \\
\text { (2009) }\end{array}$ \\
\hline Asbestos & Building insulation & $\begin{array}{l}\text { Mesothelioma (asbestos- } \\
\text { related cancer) }\end{array}$ & $\begin{array}{l}\text { EPA total ban overturned (1991); } \\
\text { many uses still banned }\end{array}$ \\
\hline
\end{tabular}

"It's a deeply

flawed bill that needs to be rewritten."

comprehensive legislation to overhaul TSCA. Mike Walls, vice-president for regulatory affairs at the council, says reforms are needed to "restore the public's confidence that chemicals can and will be used safely".

One problem with current law is that even as new methods arise for testing chemical safety, regulatory agencies must validate these techniques. Linda Birnbaum, head of the National Institute for Environmental Health Sciences in Research Triangle Park, North Carolina, notes that very low doses of endocrine disruptors can cause reproductive problems, cancers and other disorders, but they have eluded regulation. The EPA established an endocrine-disruption programme in 1998, but under current law it then had to validate new methods for testing their safety. Only in October 2009 was the agency able to request its first tests based on the new methods.

"It's important that the regulators have the flexibility to use all the available science," adds Birnbaum. For instance, the National Academy of Sciences has called for a shift away from animal-based studies to cell assays for testing the effects of chemicals on key pathways, then incorporating such data into computer models. In this and other areas, US regulators should benefit from comprehensive chemical testing being conducted under Europe's Registration, Evaluation, Authorisation and Restriction of Chemicals (REACH) legislation (see Nature 460, 1065; 2009), which came into force in June 2007.

The US chemical industry's appetite for reform has limits. Steve Risotto, a phthalate specialist at the American Chemistry Council, disagrees with the recent EPA decision to list as many as 8 phthalates as chemicals of concern. They all interfere with the male sex hormone androgen - hence the EPA's decision to list them together but only some have been linked to cancer and developmental disorders. "That's just a dog's breakfast," Risotto says. "Maybe from an academic point of view it makes sense, but from a practical point of view, it doesn't lead you anywhere."

Davies will be watching the reform efforts closely. "I'm quite optimistic that something will happen," he says. "How good it will be or how far it will go, I'm not so sure." Brendan Borrell 